\title{
New Early Jurassic gastropods from west-central Patagonia, Argentina
}

\author{
S. Mariel Ferrari \\ Acta Palaeontologica Polonica 58 (3), 2012: 579-593 doi: http://dx.doi.org/10.4202/app.2011.0090
}

A new gastropod fauna is reported from Chubut province of west-central Patagonia.

Members of Trochoidea, Pseudomelanoidea, Campaniloidea, and Nerinoidea are recorded from the Early Jurassic (Late Pliensbachian-Early Toarcian) of Mulanguińeu Formation.

The gastropod fauna consists of two new species: the pseudomelaniid Pseudomelania feruglioi sp. nov. and the protorculid Anulifera chubutensis sp. nov. Other members of the association are Pseudomelania sp.; the ampulloispirids Globularia cf. catanlilensis, Globularia sp., and Naricopsina? sp.; the nerineids Nerinea? sp. 1 and Nerinea? sp. 2; the trochids Lithotrochus humblodtii, Lithotrochus cf. rothi, and two indeterminable trochids species. An analysis of diversity was made considering all gastropod fauna recovered so far from five fossiliferous localities sampled in west-central Patagonia. The preliminary results of this study suggests that the Jurassic marine sequences of west central Chubut province are dominated by gastropods of Eucyclidae, Pseudomelaniidae, Procerithiidae, and Ampullinidae groups. However, the rarefaction curves of particular marine gastropod faunas in the Jurassic of Patagonia are still far from saturation requiring further collecting effort.

Key words: Gastropoda, Mulanguiñeu Formation, Pliensbachian, Toarcian, Chubut, Patagonia, Argentina.

Ferrari, S. Mariel [mferrari@ mef.org.ar], Museo Paleontológico “Egidio Feruglio”, CONICET, Av. Fontana 140, U9100GYO, Trelew-Chubut, Argentina.

This is an open-access article distributed under the terms of the Creative Commons Attribution License (for details please see creativecommons.org), which permits unrestricted use, distribution, and reproduction in any medium, provided the original author and source are credited. 
Full text $(941.7 \mathrm{kB})$ 
